TIM DI MUZIO AND

RICHARD H. ROBBINS
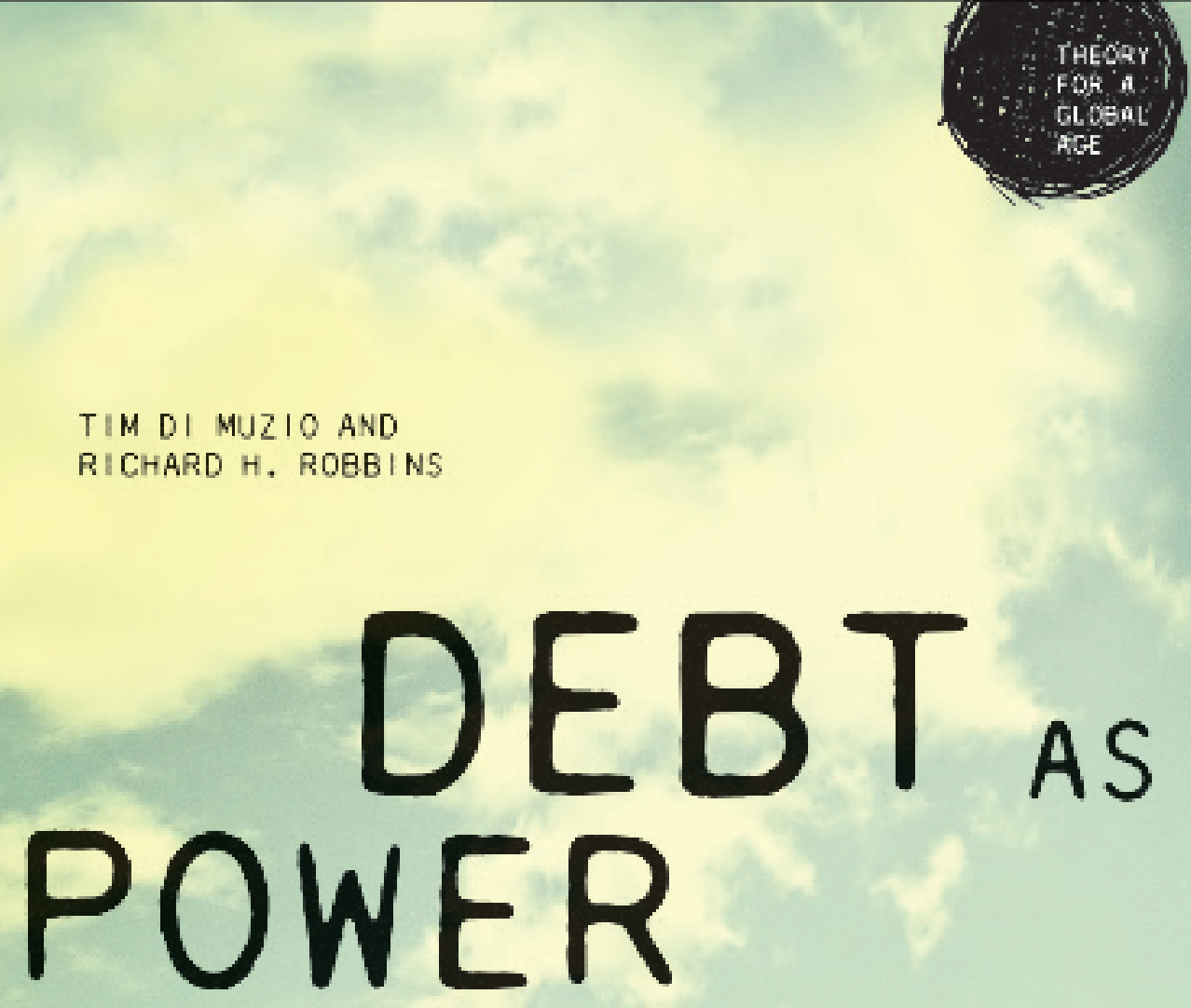

AS

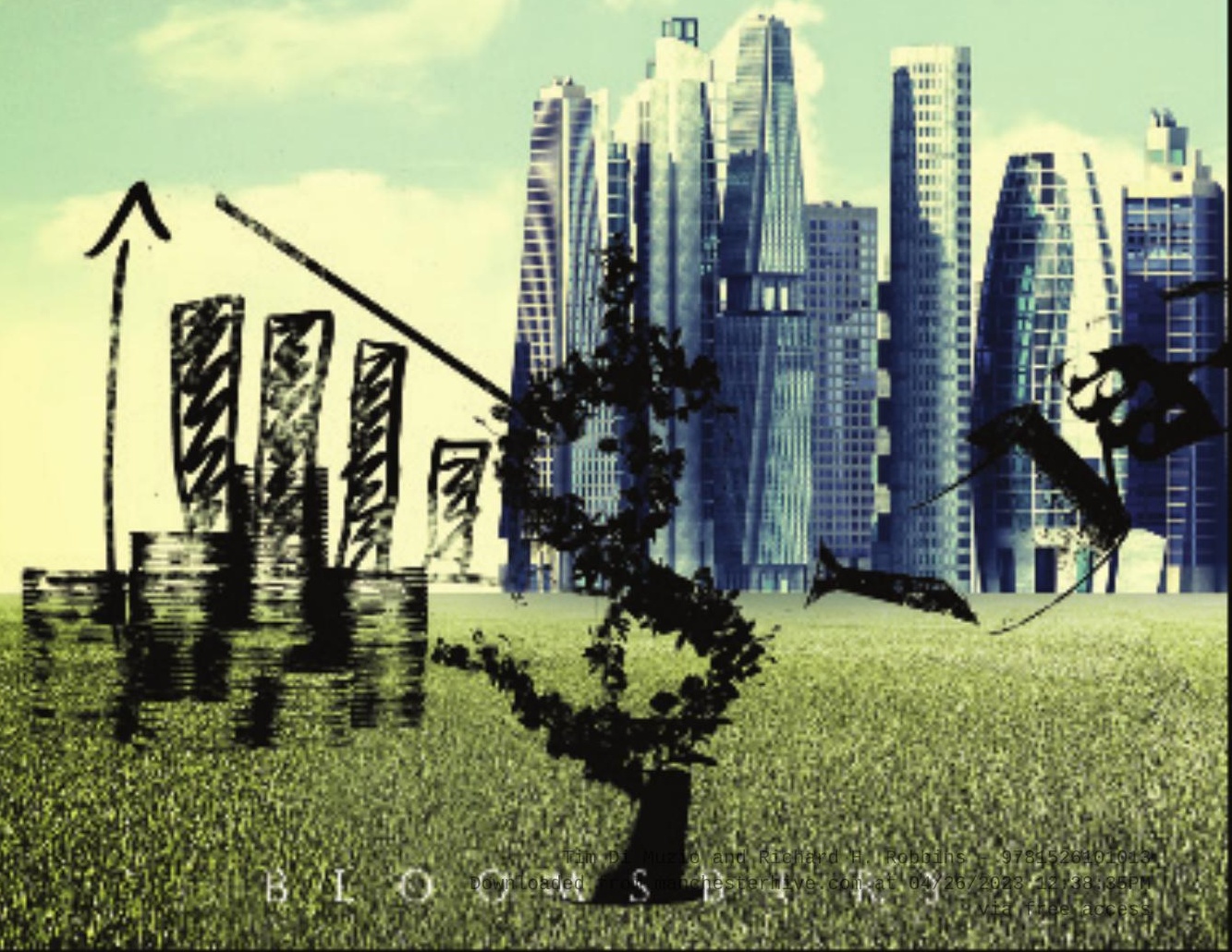




\section{Debt as Power}

\section{MANCHESTER \\ 1824}

Manchester University Press

Tim Di Muzio and Richard H. Robbins - 9781526101013 


\title{
THEORY FOR A GLOBAL AGE
}

\author{
Series Editor: Gurminder K. Bhambra
}

Globalization is widely viewed as a current condition of the world, but there is little engagement with how this changes the way we understand it. The Theory for a Global Age series addresses the impact of globalization on the social sciences and humanities. Each title will focus on a particular theoretical issue or topic of empirical controversy and debate, addressing theory in a more global and interconnected manner. With contributions from scholars across the globe, the series will explore different perspectives to examine globalization from a global viewpoint. True to its global character, the Theory for a Global Age series will be available for online access worldwide via Creative Commons licensing, aiming to stimulate wide debate within academia and beyond.

\section{Previously published by Bloomsbury: Connected Sociologies} Gurminder K. Bhambra

Eurafrica: The Untold History of European Integration and Colonialism Peo Hansen and Stefan Jonsson

Postcolonial Piracy: Media Distribution and

Cultural Production in the Global South

Edited by Lars Eckstein and Anja Schwarz

\author{
The Black Pacific: Anti-Colonial \\ Struggles and Oceanic Connections \\ Robbie Shilliam
}

Democracy and Revolutionary Politics

Neera Chandhoke 


\title{
Debt as Power
}

\author{
Tim Di Muzio and Richard H. Robbins
}

Manchester University Press 
The right of Tim Di Muzio and Richard H. Robbins to be identified as the authors of this work has been asserted by them in accordance with the Copyright, Designs and Patents Act 1988.

Published by Manchester University Press

Altrincham Street, Manchester M1 7JA

www.manchesteruniversitypress.co.uk

British Library Cataloguing-in-Publication Data

A catalogue record for this book is available from the British Library

\section{$($ (ㅇ) $(\$)$}

This work is published subject to a Creative Commons Attribution Non-commercial No Derivatives Licence. You may share this work for non-commercial purposes only, provided you give attribution to the copyright holder and the publisher. For permission to publish commercial versions please contact Manchester University Press.

Library of Congress Cataloging-in-Publication Data applied for

$\begin{array}{rll}\text { ISBN } & 9781784993252 & \text { hardback } \\ 9781784993269 & \text { paperback } \\ 9781526101013 & \text { open access }\end{array}$

First published 2016

The publisher has no responsibility for the persistence or accuracy of URLS for any external or third-party internet websites referred to in this book, and does not guarantee that any content on such websites is, or will remain, accurate or appropriate.

Typeset by Integra Software Services Pvt. Ltd. 